\title{
Summer feeding ecology of Great Pampa-finches, Embernagra platensis at Laguna de Guaminí, Buenos Aires, Argentina
}

\author{
LAURA M. FERMAN and DIEGO MONTALTI \\ Department of Ornithology, Museo de Ciencias Naturales de La Plata \\ Paseo del Bosque, B1900FWA, La Plata, Argentina \\ Manuscript received on January 10, 2008; accepted for publication on May 12, 2010
}

\begin{abstract}
The aim of this study was to assemble data on the summer feeding ecology of the Great Pampa-finch, Embernagra platensis at the Laguna de Guaminí, Buenos Aires, Argentina, and to explore the differences related to the dietary patterns for each sex between winter and summer when possible. The stomach contents of 43 birds were analyzed. The animal fraction was composed of Hymenoptera (45.1\%), Coleoptera (32.4\%), Lepidoptera (6.0\%), Araneae (5\%) and Orthoptera (3.2\%). The application of the index of relative importance (IRI) resulted in 1490.4 for Coleoptera, 428.5 for Hymenoptera and 162.5 for Lepidoptera caterpillars. The vegetal fraction consisted of Triticum aestivum (26.9\%), Cyperaceous (25\%), Poaceae (Gramineae) (19.3\%) and Panicum sp. (11.2\%). The IRI values were 893.8 for Triticum aestivum, 174.5 for Gramineae, 126.5 for Panicum sp. and 112.8 for Scirpus sp. The food niche width was 0.33 for both sexes; the diversity index resulted in 1.06 for females and 1.33 for males and specific diversity ranged from 1.87 to 2.84 . A canonical component analysis (CCA) was performed on environmental and morphometric variables, and a Monte Carlo test confirmed the canonical correlations. A t-test showed that some birds harmonized with a logarithmic model and some with a geometric curve. During the summer, Embernagra platensis ingests Hymenoptera and Coleoptera more often than seeds, suggesting that two biological mechanisms could be taking place in this bird.
\end{abstract}

Key words: Argentina, Embernagra platensis, feeding ecology, Great Pampa-finch.

\section{INTRODUCTION}

The Great Pampa-finch, Embernagra platensis, belongs to the Emberizinae finches, distributed from the southeast Brazil (north of Minas Gerais to Espírito Santo), through most of Paraguay (local in the dry Chaco), northwest Bolivia (north to Beni), and Uruguay, to central and south Argentina (Misiones, Formosa, Chaco, Santa Fé, La Pampa and Río Negro (Short 1975, Ridgely and Tudor 1989)).

It inhabits open grasslands, often with scattered shrubs, and can fairly frequently be seen flying along and over roadsides, although some prefer damp places. They form pairs or small groups, are territorial and consistently sing while perched on the top of bushes and fence posts (Ridgely and Tudor 1989, Hayes 2003).

Correspondence to: D. Montalti

E-mail: dmontalti@arnet.com.ar
Previous papers on the Great Pampa-finch registered mainly arthropods, mostly insects as its potential preys (Marelli 1919, Aravena 1928, Zotta 1932, 1936, 1940, Montalti et al. 2005). Beltzer (1990) reported that the diet of Embernagra platensis in the middle valley of the Río Paraná (Province of Santa Fé, Argentina) was dominated by an animal fraction (16 taxa), followed by a plant fraction ( 8 taxa). Current feeding studies carried out at the Laguna de Guaminí during the winter registered arthropods (40\% biomass), mostly Formicidae and Coleoptera, and typical seeds of the Pampas (60\% biomass) as part of its diet (Montalti et al. 2005). The previously known facts about the dietary composition of the Great Pampa-finch were incomplete, based on a small number of samples or isolated data. In this sense, the purpose of this study was to provide information about the feeding ecology of E. platensis during 
the summer, compare its diet between seasons and sexes at the Laguna de Guaminí, Province of Buenos Aires, Argentina.

\section{METHODS}

\section{STUDY AREA}

This research was carried out in the area of the Laguna de Guaminí $\left(37^{\circ} 1^{\prime} 60 \mathrm{~S}, 62^{\circ} 25^{\prime} 0 \mathrm{~W}\right)$, near the neighboring city of Guaminí, in the Province of Buenos Aires, which is part of the biogeographical province of Pampa. The dominant climate is temperate semiarid, with thermal fluctuations ranging from $15.2^{\circ} \mathrm{C}$ to $7^{\circ} \mathrm{C}$. The vegetation arrangement corresponds to an herbaceous steppe or sub-steppe. Natural grasslands have been reduced and replaced by annual crops. The winter harvest includes oat, wheat, and rye, while the summer crops are of sunflower, corn, soy and sorghum.

\section{STOMACH SAMPLES}

Great Pampa-finches at the Laguna de Guaminí were collected $(\mathrm{N}=43)$ with the permission of the Dirección Provincial de Recursos Naturales de la Provincia de Buenos Aires in December 1997. Birds were sexed, measured, weighed and promptly frozen. The stomach contents were collected in numbered plastic bags; the samples were processed to avoid stomach decomposition and, then, transferred into glass containers and preserved in $70 \%$ ethyl alcohol. The minimum number of prey individuals in each stomach sample was determined using diagnostic fragments, such as head capsules, caterpillar mandibles, elytra and wings (Yard and Blake 2002). Insect determination was carried out using the classifications by Merrit and Cummins (1978) and Kusnezov (1978). The systematic determination of plant species was made following Cronquist (1993). The minimum sample was calculated using the collected stomachs (represented by each individual) and taxa (prey items).

\section{Statistical AnALYsis}

In this study, the relationship between prey item variables and the variation explained by morphometric measurement variables (environmental variables) was examined. The association among birds (sample variables), items consumed by the species (species variables) and morphometric measurements (environmental variables) of birds were also analyzed. All data were combined in a matrix. The associations between sets of two variables were investigated performing a canonical correlation analysis (CCA) using the Canoco statistical software.

In order to compare diet patterns through the diversity index among groups from different seasons, statistical tests were carried out using SYSTAT 7.0. When running the program, we operated with groups of birds collected in each season as "different communities", and prey species items were named by taxonomical category. We worked with four sets of data named from ' $\mathrm{C} 1$ ' to ' $\mathrm{C} 4$ ', and with the abundances of prey items. In the analysis, ' $\mathrm{C} 1$ ' refers to summer males, ' $\mathrm{C} 2$ ' to summer females, 'C3' to winter males, and ' $\mathrm{C} 4$ ' to winter females (Montalti et al. 2005).

The abundance range hypothetical model method was used to determine whether the real data fit the hypothetical model curves of richness-abundance. The model curves tried were logarithmic, geometric and broken stick shaped. The analysis evaluates and compares biodiversity community rates. We worked with ' $\mathrm{C} 1$ ' to ' $\mathrm{C} 4$ ' and proposed hypothetical curves for each community using SYSTAT 7.0.

The food niche breadth (FNB) was calculated using Levins' index (Levins 1968, Krebs 1989), as $1 /\left(\sum p_{i} 2\right)$, where $p_{i}$ is the proportion of prey $i$ in the diet. A standardized food niche breadth value (FNBst) was calculated, as $(F N B-1) /(n-1)$, where $n$ is the total number of prey categories (Colwell and Futuyma 1971). Lower values of Levins' index indicate relatively more specialized species, whereas higher values indicate more generalized ones (Krebs 1989).

The importance relative index (IRI) was used to establish prey contribution to diet composition. The H' index (Shannon and Weaver 1949) was calculated between seasons and sexes, and a $t$-test was also used in order to compare the differences in diversity indices among the communities mentioned above.

\section{RESULTS}

During the summer period, all stomachs (43) contained arthropod items, but 26 contained seeds. The minimum sample was estimated in 53 items. Analysis showed that 
the food (g) eaten by the Great Pampa-finch consisted primarily of arthropods (83\%) and seeds $(17 \%)$. Table I shows the arthropod fraction consumed in terms of importance by number (N) and by frequency of occurrence $(\mathrm{F})$. The reported insects were Hymenoptera (Formicidae), 45.1\%; Coleoptera (Curculionidae, Carabidae), 32.4\%; Lepidoptera caterpillars, 6\%; Araneae, $5 \%$; and Orthoptera, $3.2 \%$. In the Hymenoptera, Formicidae fraction, we distinguished leaf-cutter ants, winged reproductive individuals and small red-colored ants.

Insect length ranged from $5.5 \mathrm{~mm}$ in Curculionidae and Formicidae to $30 \mathrm{~mm}$ in Lepidoptera caterpillars. The resultant IRI for the arthropod fraction was 1490.4 (149\%) for Coleoptera, 428.5 (42.85\%) for Hymenoptera, and $162.5(16.25 \%)$ was represented by Lepidoptera caterpillars.

Table II shows the plant species ingested by number and frequency of occurrence. Seeds were Triticum sp. (26.9\%), Scirpus sp. (25.1\%), Poaceae (Gramineae, 19.3\%) and Panicum sp. (11.2\%). Seed size ranged from $1 \mathrm{~mm}$ in Chenopodium sp. to $7 \mathrm{~mm}$ in Triticum aestivum. The IRI for the vegetal fraction resulted in 893.8 (89.38\%) for Triticum aestivum, 174.5 (17.45\%) for Poaceae (Gramineae), 126.5 (12.65\%) for Panicum sp., and 112.8 (11.28\%) for Scirpus sp.

The trophic spectrum based on the identification of 507 items was integrated by 41 taxa ( 9 plants and 32 insects) and the standard FNB resulted in 0.33 for the summer period. Gastroliths ( 5 samples) ranged between 1 and $2 \mathrm{~mm}$.

The mean stomach sample was $0.57 \mathrm{~g}(\mathrm{SD} \pm 0.21)$ and it ranged from $0.16 \mathrm{~g}$ to $1.36 \mathrm{~g}$, representing $c a$. $1.36 \%$ of the body mass. The mean body mass was $41.7 \mathrm{~g}$, and the mean number of items was 12 per stomach per bird for the summer.

The H' index was 2.24 for males and 1.94 for females during the summer. The diversity index was 1.08 for males and 1.5 for females during the winter, and there was no difference between these seasons.

Table III shows in the CCA analysis that the second components contemplate about $71 \%$ of the information among variables, meaning that the samples (birds) correlate with environmental variables (morphometrics). The Monte Carlo test supports the CCA analysis with a test of significance of the first canonical axis (eigen-value)
TABLE I

Insect species by number $(\mathrm{N})$ and frequency (F) of occurrence consumed by Embernagra platensis during the summer at the Laguna de Guaminí.

\begin{tabular}{|c|c|c|c|c|}
\hline Insect species & $\mathrm{N}$ & $\mathrm{N} \%$ & $\mathrm{~F}$ & $\mathrm{~F} \%$ \\
\hline LEPIDOPTERA & & & & \\
\hline Caterpillars & 17 & 5.98 & 8 & 18.60 \\
\hline COLEOPTERA & & & & \\
\hline Curculionidae & 41 & 14.43 & 16 & 32.20 \\
\hline Lucanidae & 1 & 0.35 & 1 & 2.32 \\
\hline Tenebrionidae & 2 & 0.70 & 2 & 4.65 \\
\hline Buprestidae & 6 & 2.11 & 3 & 6.97 \\
\hline Carabidae & 32 & 11.26 & 20 & 46.51 \\
\hline *Undeterm. Coleoptera & 10 & 3.52 & 8 & 18.60 \\
\hline HEMIPTERA & & & & \\
\hline Belostomatidae & 1 & 0.35 & 1 & 2.32 \\
\hline Cicadellidae & 1 & 0.35 & 1 & 2.32 \\
\hline *Undeterm. Hemiptera & 5 & 1.76 & 5 & 11.62 \\
\hline HETEROPTERA & & & & \\
\hline Pentotomidae & 1 & 0.35 & 1 & 2.32 \\
\hline DICTIOPTERA & & & & \\
\hline Blattidae & & & & \\
\hline Periplaneta americana & 1 & 0.35 & 1 & 2.32 \\
\hline Mantoidea & & & & \\
\hline Mantis religiosa & 2 & 0.70 & 1 & 2.32 \\
\hline ORTOPTERA & & & & \\
\hline SubO. Ensifera & 2 & 0.70 & 2 & 4.65 \\
\hline SubO. Celifera & 4 & 1.41 & 3 & 6.97 \\
\hline *Undeterm. Orthoptera & 3 & 1.05 & 3 & 6.97 \\
\hline HYMENOPTERA & & & & \\
\hline *Formicidae & 120 & 42.25 & 12 & 28.0 \\
\hline Undeterm. Formicidae & 4 & 1.41 & 4 & 9.30 \\
\hline Apidae & 2 & 0.70 & 2 & 4.65 \\
\hline Vespidae & 1 & 0.35 & 1 & 2.32 \\
\hline Symphyta sp. & 1 & 0.35 & 1 & 2.32 \\
\hline ODONATA & & & & \\
\hline SubO. Anisoptera & 3 & 1.05 & 2 & 4.65 \\
\hline *Undeterm. Odonata & 2 & 0.70 & 2 & 4.65 \\
\hline DERMAPTERA & & & & \\
\hline Forcicula sp. & 1 & 0.35 & 1 & 2.32 \\
\hline DIPTERA & & & & \\
\hline Brachicera & & & & \\
\hline Muscidae & & & & \\
\hline Musca sp. & 2 & 0.70 & 2 & 4.65 \\
\hline Simulidae & 5 & 1.76 & 1 & 2.32 \\
\hline
\end{tabular}


TABLE I (continuation)

\begin{tabular}{l|c|c|c|c}
\hline \multicolumn{1}{c|}{ Insect species } & $\mathrm{N}$ & $\mathrm{N} \%$ & $\mathrm{~F}$ & $\mathrm{~F} \%$ \\
\hline ARANEA & & & & \\
Opilionidae & 1 & 0.35 & 1 & 2.32 \\
Lagnatore & & & & \\
Araneida & & & & \\
Lycosidae & 6 & 2.11 & 2 & 4.65 \\
Lycosa sp. & 1 & 0.35 & 1 & 2.32 \\
Pseudoescorpionidae & 6 & 2.11 & 6 & 13.95 \\
*Undeterm. Araneida &
\end{tabular}

Undeterm. = undetermined fraction due to decomposition. We used body structures for classification. Total number of insects $=284$. Total stomach contents $=43$. ${ }^{*}$ Formicidae (Atta sp., Solenopsis saevissima, Acromyrmex lundi and Acromirmex striatum).

\section{TABLE II}

Plant species number $(\mathrm{N})$ and frequency $(\mathrm{F})$ of occurrence consumed by Embernagra platensis during the summer at the Laguna de Guaminí.

\begin{tabular}{l|c|c|c|c}
\hline \multicolumn{1}{c|}{ Plant species } & $\mathrm{N}$ & $\mathrm{N} \%$ & $\mathrm{~F}$ & $\mathrm{~F} \%$ \\
\hline DICOTYLEDONEAE & & & & \\
\hline CHENOPODIACEA & & & & \\
Chenopodium sp. & 16 & 7.17 & 3 & 6.97 \\
\hline MONOCOTYLEDONEAE & & & & \\
Cyperaceae & & & & \\
Scirpus sp. & 56 & 25.11 & 2 & 4.65 \\
\hline POACEAE (Gramineae) & 43 & 19.28 & 4 & 9.30 \\
Triticum aestivum & 60 & 26.90 & 14 & 32.55 \\
Paspalum sp. & 14 & 6.27 & 2 & 4.65 \\
Panicum sp. & 25 & 11.21 & 5 & 11.62 \\
Leptochloa sp. & 2 & 0.89 & 2 & 4.65 \\
Schizochinum sp. & 1 & 0.44 & 1 & 2.32 \\
* Undeterm. Plants & 6 & 2.69 & 6 & 13.95 \\
\hline
\end{tabular}

*Undeterm. $=$ undetermined fraction due to deterioration, material that was weighed and contributed to the diet but that couldn't be classified as a plant gender or species. Total number of plants $=223$.

of about 0.016 (F-ratio $=42.287$; P-value $=0.002)$. The test of significance of all canonical axes (trace) was 0.041 (F-ratio $=139.205 ; \mathrm{P}$-value $=0.002)$. The first two canonical correlations were significant, representing a good association between the two sets of variables.

The $t$-test for the abundance range hypothetical model curves showed that ' $\mathrm{C} 1$ ' (summer males) and ' $\mathrm{C} 3$ ' (winter males) paired better with the logarithmic model curve $(p=0.45, d f=8 ; p=0.30, d f=10)$. On the other hand, 'C2' (summer females), and 'C4' (winter females) paired better with the geometric curve $\left(\mathrm{p}=2.5 \times 10^{6}\right.$; $\mathrm{p}=5.2 \pm 10^{6}$ ). During the summer, ' $\mathrm{C} 1$ ' (males) consumed 393 preys of 21 species; 'C2' (females) 119 preys of 16 species. During the winter, 'C3' (males), ingested 485 preys of 11 species, and ' $\mathrm{C} 4$ ' (females) consumed 423 preys of 11 species.

Tables IV and $\mathrm{V}$ show the mean values of diet items for the winter and summer, based on 38 and 43 stomach contents, respectively.

\section{DISCUSSION}

In order to discuss the feeding ecology of the Great Pampa-finch during the summer, we made some comparisons concerning the proportions and the diversity of prey items ingested between the two seasons when possible. The specimens collected had consumed 17\% of seeds (biomass) in the summer and 60\% in the winter. Plant seed families were Chenopodiaceae, Asteraceae, Cyperaceae, and Poaceae for the winter, and they differed from the summer in certain species, namely $\mathrm{He}$ lianthus annuus, Setaria ssp., Zea mays, and Eleusine tristachia (Montalti et al. 2005). The summer plant species diverged considerably from the winter species (Table II), but they were all local components, both cultivated and ornamental crops. We assume that the undetermined vegetal fraction was obtained as part of indigestible seed husks and grass that were picked while birds were eating fallen seeds. Wheat and corn were obtained from leftover crops at the end of August-November. The harvesting activity spreads native and exotic seeds, but also grain storage offers "free" nourishment, especially for pest insects commonly preyed upon seedeating birds. Even though seeds are important components of the winter diet, during the nesting season most of the birds feed on insects. Energy and protein requirements increase in birds during breeding (Klasing 1998). Arthropod ingestion provides more nutrients than fruit for most passerine birds (Izhaki 1998). During the summer, the amount of seeds and gastroliths decreased in comparison with the winter (Montalti et al. 2005).

The animal fraction found in the Great Pampa-finch was $83 \%$ (biomass) during the summer, quite larger if we compare it to $39 \%$ in the winter (Montalti et al. 2005). The reported insects were mainly Formicidae 
TABLE III

CCA analysis summarizing the correlation among variables and the information explained by axes.

\begin{tabular}{l|c|c|c|c|c}
\hline \multicolumn{1}{c|}{ Axes } & 1 & 2 & 3 & 4 & $\begin{array}{c}\text { Total } \\
\text { inertia }\end{array}$ \\
\hline Eigen values & 0.016 & 0.013 & 0.006 & 0.003 & 0.044 \\
\hline Species environment correlation & 0.962 & 0.981 & 0.993 & 0.939 & \\
\hline $\begin{array}{l}\text { Cumulative percentage variance } \\
\text { of species data } \\
\text { of species-environment relation }\end{array}$ & 37.3 & 67.1 & 80.6 & 86.4 & \\
\hline Sum of all eigen-values & 39.4 & 70.9 & 85.1 & 91.3 & \\
\hline Sum of all canonical eigen-values & & & & & 0.044 \\
\hline
\end{tabular}

All four eigen-values reported above are canonical and correspond to axes that are constrained by the environmental variables.

TABLE IV

Mean winter dietary item values of Embernagra platensis at the Laguna de Guaminí during July 2000 (Montalti et al. 2005).

\begin{tabular}{l|c|c|c|c|c|c|c|c}
\hline & TW & GN & GW & SN & SW & IN & IW & ItN \\
\hline Mean* & 1.13 & 16.54 & 0.25 & 11.17 & 0.59 & 19.09 & 0.41 & 27.21 \\
\hline Ds & 0.28 & 12.78 & 0.32 & 9.75 & 0.39 & 23.51 & 0.34 & 24.14 \\
\hline Min. & 0.62 & 2 & 0.01 & 1 & 0.01 & 1 & 0.04 & 2 \\
\hline Max. & 1.8 & 50 & 1.11 & 43 & 1.4 & 77 & 1.23 & 104 \\
\hline $\mathrm{N}$ & 38 & 28 & 30 & 36 & 36 & 33 & 34 & 38 \\
\hline Total & & & & 391 & & 630 & & 1034 \\
\hline
\end{tabular}

*Mean values were based on $\mathrm{N}=38$ stomach contents collected during the winter. $\mathrm{TW}=$ total stomach content weight, GN = number of gastroliths, GW = weight of gastroliths, $\mathrm{SN}=$ seed number, $\mathrm{SW}=$ seed weight, $\mathrm{IN}=$ insect number, $\mathrm{IW}=$ insect weight, $\mathrm{ItN}=$ number of items.

TABLE V

Mean summer dietary items values of Embernagra platensis at the Laguna de Guaminí during December 1997.

\begin{tabular}{l|c|c|c|c|c|c|c|c}
\hline & TW & GN & GW & SN & SW & IN & IW & ItN \\
\hline Mean \# & 0.57 & 0.82 & 0.01 & 7.19 & 0.21 & 7.39 & 0.40 & 11.95 \\
\hline Ds & 0.21 & 2.22 & 0.02 & 11.10 & 0.20 & 9.77 & 0.40 & 13.44 \\
\hline Min. & 0.16 & 0 & 0 & 0 & 0 & 1 & 0 & 1 \\
\hline Max. & 1.16 & 10 & 0.06 & 56 & 0.66 & 50 & 1.77 & 63 \\
\hline $\mathrm{N}$ & 43 & 22 & 22 & 26 & 26 & 43 & 43 & 43 \\
\hline Total & & & & 223 & & 284 & & 507 \\
\hline
\end{tabular}

\# Mean values were based on 43 stomach contents collected during the summer. TW $=$ total stomach content weight, $\mathrm{GN}=$ number of gastroliths, $\mathrm{GW}=$ weight of gastroliths, $\mathrm{SN}=$ seed number, $\mathrm{SW}=$ seed weight, $\mathrm{IN}=$ insect number, $\mathrm{IW}=$ insect weight, ItN $=$ number of items.

and Coleoptera. The summer dietary components were terrestrial insects, such as the $44.1 \%$ of Formicidae (biomass) represented by Acromyrmex sp. and Atta sp. We suggest that some ants were captured from the ground and some were winged reproductive individuals that were trapped during short flights. We also found Solenopsis saevissima, Acromyrmex lundi and Acromyrmex striatum in both seasons. During the summer, the Great Pampa-finch had ingested a high diversity of prey items, especially flying insects such as Odonata, Ortoptera, 
Blattidae, Coleoptera, and Hymenoptera, compared to the winter even though they had eaten a larger quantity of preys. The presence of Araneae, Lycosidae, Carabidae, Curculionidae and Tenebrionidae may suggest that birds are digging the ground, removing leaves, tree barks and tissues, and exploring soil surfaces. Dermaptera (Forcicula sp.) and Heteroptera (Periplaneta sp.) are not abundant, but we suggest that they were trapped during flying displays or while scavenging the soil stratum. A similar dietary diversity was registered in South African passerine birds also composed by beetles, termites, berries, seeds and ants (Kopij 2003, 2005).

Aquatic arthropods were represented by larval stages of Odonata (dragonflies) and Hemiptera such as Belostoma sp., that were found in six different samples (Beltzer 1990). We found several brownish and greenish caterpillars. A diversity measurement gave us the trophic spectrum, which was composed of 41 taxa $(9$ plants, 32 arthropods) for the summer and 21 (9 plants, 12 arthropods) for the winter (Montalti et al. 2005).

During the summer, the mean seed weight of the content $(0.57 \mathrm{~g}, \mathrm{SD} \pm 0.21)(0.21 \mathrm{~g})$ was half of the mean weight encountered for the winter (Tables IV and V), which was $1.6 \%$ and $3 \%$ of the body mass, respectively. Other summer values resulted in a minor proportion in comparison to the values of the winter. The items consumed throughout the summer were also half in quantity (abundance) in comparison with the winter period. This behavior could be related to the feeding period of chicks. However, variety in the trophic spectrum was higher during the summer, whereas the mean body weight was similar for both seasons (Tables IV and V).

Concerning the animal fraction, we would like to emphasize the proportion of ants in the diet of Embernagra platensis, which is notorious and very abundant when compared to other insect proportions. Beltzer (1990) found Atta sp. and Acromyrmex sp., the same genus found in this study for both seasons. These "leafcutter ants" can be universally found in a variety of ecosystems. $44.1 \%$ of ants (out of a total of $83 \%$ of insect biomass for the summer) and 39\% (out of a total of $95.8 \%$ for the winter) are too many ants for a seedeating bird species. Curiously, the Great Pampa-finch could be developing some kind of natural control on harmful insects. In the same line, this bird could be showing a behaviour indulged in by birds called "anting". Many bird species have been observed picking up ants and rubbing them on their plumage, a behavior which is displayed frequently (Clark and Clark 1990). Most anting reports involve passerines, especially of the Corvidae, Sturnidae and Emberizidae families (Wenny 1998) but, in fact, though anting is not well understood yet, birds seem to acquire the defensive secretions of ants due to their fungicidal and bactericidal properties. Video-recording could be a helpful tool in case of laboratory experiments, but what happens during the anting behavior is not known. These finches could be performing a defensive treatment by using ants or stimulating the formic acid discharge before eating them because of their taste. In this sense, the Great Pampa-finch could naturally be displaying some kind of pest biological control in local agriculture, feeding on harmful insects, ants and beetles (e.g. Curculionidae). This could be an auspicious hint of an opportunity to study some of the feeding mechanisms that Embernagra platensis uses.

\section{ACKNOWLEDGMENTS}

This work was part of an integral research program carried out by many groups of investigators researching in the same Laguna de Guaminí area. We want to thank the Dirección Provincial de Recursos Naturales de la Provincia de Buenos Aires (Direction of Natural Resources of the Province of Buenos Aires) for the permission granted according to federal laws to do research in this area in December 1997. We also want to thank Magdalena Ponce for manuscript corrections.

\section{RESUMO}

O objetivo deste estudo foi reunir dados referentes à ecologia alimentar do Sabiá-do-banhado, Embernagra platensis, na laguna de Guaminí, Buenos Aires, Argentina, e explorar as diferenças relacionadas aos padrões dietéticos para cada sexo entre inverno e verão, quando possível. O conteúdo estomacal de 43 pássaros foi analisado. A fração animal foi composta por Hymenoptera $(45,1 \%)$, Coleoptera $(32,4 \%)$, Lepidoptera $(6,0 \%)$, Araneae (5\%) e Orthoptera (3,2\%). A aplicação do índice de importância relativa (IRI) resultou em 1.490,4 para Coleoptera, Hymenoptera e 428,5 para 162,5 lagartas de Lepidoptera. A fração vegetal consistiu de Triticum aestivum 
(26,9\%), Cyperaceous (25\%), Poaceae (Gramineae) (19,3\%) e Panicum sp. (11,2\%). Os valores de IRI foram 893,8 para Triticum aestivum, 174,5 para Gramineae, 126,5 para Panicum sp. e 112,8 para Scirpus sp. A largura do nicho alimentar foi 0,33 para ambos o sexos; o índice de diversidade resultou em 1,06 para fêmeas e 1,33 para machos, e a diversidade específica variou de 1,87 a 2,84. A análise canônica de componentes (ACC) foi realizada nas variáveis ambientais e morfométricas, e o teste de Monte Carlo confirmou as correlações canônicas. O teste- $t$ mostrou que alguns pássaros harmonizaram com um modelo logarítmico e alguns com uma curva geométrica. Durante o verão Embernagra platensis ingere Hymenoptera e Coleoptera com mais frequência do que sementes, sugerindo que dois mecanismos biológicos poderiam estar ocorrendo neste pássaro.

Palavras-chave: Argentina, Embernagra platensis, ecologia alimentar, Sabiá-do-banhado.

\section{REFERENCES}

ARAVEnA RO. 1928. Notas de alimentación de algunas aves. Hornero 4: 153-166.

Beltzer AH. 1990. Biología alimentaria del Verdón Común Embernagra platensis platensis (Aves: Emberizidae) en el Valle aluvial del río Paraná Medio, Argentina. Orn Neot 1: 25-30.

Clark CC and Clark L. 1990. Anting behavior by Common Grackles and European Starlings. Wilson Bull 102: $167-169$.

Colwell RK and Futuyma DJ. 1971. On the measurement of niche breadth and overlap. Ecology 52: 567-576.

CRONQUIST A. 1993. The evolution and classification of flowering plants. New York: New York Botanical Garden, Bronx, $555 \mathrm{p}$.

Hayes FE. 2003. Geographic variation in the Great PampaFinch Embernagra platensis complex: evidence for two species. Ardeola 50: 223-235.

IZHAKI I. 1998. Essential amino acid composition of fleshy fruits versus maintenance requirements of passerine birds. J Chem Ecol 24: 1333-1345.

KLASING K. 1998. Comparative Avian Nutrition. New York: Oxford University Press, $350 \mathrm{p}$.

KopIJ G. 2003. Diet of some species of Turdidae in South African grasslands: short communication. SAJWR 33: 55-59.
KOPIJ G. 2005. Diet of some insectivorous passerines in semi-arid regions of South Africa. Ostrich 76: 85-90.

Krebs CJ. 1989. Ecological Methodology. New York: Harper Collins Pub, 654 p.

Kusnezov N. 1978. Claves para la identificación de las hormigas de la fauna argentina. Ministerio de Agricultura y Ganadería, Buenos Aires, p. 1-56.

LEvins R. 1968. Evolution in Changing Environments. Princeton, N.J.: Princeton University Press, 120 p.

MARELli CA. 1919. Sobre el contenido estomacal de algunas aves. Hornero 1: 221-228.

MerRit RW AND Cummins KW. 1978. An introduction to the aquatic insects of North America. Debuque: KendallHunt Pub Co, 441 p.

Montalti D, Ferman L, CAmperi AR, SoAve GE, ARAMBARRI AM AND DARRIEU CA. 2005. Winter diet of Embernagra platensis platensis in Guaminí Lagoon, Argentina. Acta Ornithol 40: 79-82.

RIdGely RS AND TUdor G. 1989. The birds of South America. Vol. 1. The Oscines Passerines. Austin: University Texas Press, $814 \mathrm{p}$.

Shannon CE AND WeAVER W. 1949. The Mathematical Theory of Communication. Urbana: University of Illinois Press, $144 \mathrm{p}$.

SHORT LL. 1975. A zoogeographic analysis of the South American Chaco avifauna. Bull Amer Mus Nat Hist 154: 165-352.

WENNY D. 1998. Three-stripped Warbler (Basileuterus tristriatus) "Anting" with a caterpillar. Wilson Bull 110: 128131.

YARD HK AND BLAKE JG. 2002. Inventory and Monitoring of Terrestrial Riparian Resources in the Colorado River Corridor of Grand Canyon, An Integrative Approach. Annual Report. Cooperative Agreement 01WRAG0044 and 01WRAG0034.

ZotTA A. 1932. Notas sobre el contenido estomacal de algunas aves. Hornero 5: 77-81.

ZotTA A. 1936. Sobre el contenido estomacal de aves Argentinas. Hornero 6: 261-270.

ZоттA A. 1940. Listado del contenido estomacal de aves Argentinas. Hornero 7: 402-411. 